\title{
Movement control as an effective measure against Covid-19 spread in Malaysia: an overview
}

\author{
Kuok Ho Daniel Tang ${ }^{1}$ (D)
}

Received: 24 April 2020 / Accepted: 16 May 2020 / Published online: 13 June 2020

(C) Springer-Verlag GmbH Germany, part of Springer Nature 2020

\begin{abstract}
Aim The first Covid-19 cases were reported in Malaysia on 25 January 2019 followed by a quiescent period before an upward swing of the cases at the end of February 2020, partly attributed to mass gathering during a religious event. This short communication aims to provide an overview of the measures taken by the Malaysian Government in response to Covid-19, and of the effectiveness of the Movement Control Order.

Subjects and methods This short communication reviews articles and government announcements related to containment measures and the Movement Control Order of Malaysia, and graphically presents data pertinent to Covid-19 in Malaysia in order to show the relationship between fluctuations in Covid-19 cases and movement control.

Results At the onset of the Covid-19 outbreak, Malaysia had initiated travel restrictions and quarantine; but with a persistent increase in new Covid-19 cases, the Movement Control Order was finally rolled out on 18 March 2020, requiring closure of all businesses except those providing essential services and items. Enforcement of the order was tightened progressively, resulting in significant improvement of compliance, while other interventions such as tracking of potential contacts and medical screening were underway, and the media continued to provide updates and general advices. The numbers of new and active Covid-19 cases started showing evident downtrends from mid-April, thus indicating the effectiveness of movement control and its compliance. Conclusion The article provides insight into crucial factors contributing to the success of movement control to effectively contain Covid-19, and highlights the need to prevent future upsurge through continuous monitoring and enforcement.
\end{abstract}

Keywords Covid- 19 - Coronavirus $\cdot$ Malaysia $\cdot$ MCO $\cdot$ SARS-CoV-2

\section{Introduction}

Covid-19 was first detected in Malaysia on 25 January 2020 among three Chinese citizens who entered Malaysia through Singapore on 23 January 2020 (Pung et al. 2020). On 30 January 2020, there was a total of eight confirmed cases of Covid-19, all involving Chinese citizens (Bernama 2020a). The first local infection of Covid-19 was identified on 4 February 2020, and the number of infected individuals remained below 25 until 1 March, when the number of cases increased to 29 (Ministry of Health Malaysia 2020). The total number of Covid-19 cases then increased steadily before a sharp rise starting on 14 March (Fig. 1). The first two deaths

Kuok Ho Daniel Tang

daniel.tang@curtin.edu.my

1 Health, Safety and Environment Programme, Curtin University Malaysia, CDT 250, 98009 Miri, Sarawak, Malaysia due to Covid-19 were reported on 17 March (See et al. 2020) (Fig. 2), after which cases of death increased steadily, though the number remained below 100 until 29 April (Fig. 2). As of 30 April, the mortality rate due to Covid- 19 was $1.70 \%$, which was lower than the global average of $7.1 \%$ (World Health Organization 2020).

The soaring number of Covid-19 infected individuals in Malaysia after 14 March was believed to be linked to a religious event in Kuala Lumpur from 27 February to 1 March attended by an estimated 16,000 people, approximately 1,500 of whom came from other Southeast Asian countries (Bernama 2020a). About $65 \%$ of the 673 cumulative Covid19 cases reported on 17 March were traced to the religious event (Ministry of Health Malaysia 2020). A surge in the number of infected people also resulted in significant rise of active Covid-19 cases which weighted on the nation's healthcare capacity (Salim et al. 2020). The daily new Covid-19 cases have been consistently above 100 between 15 March and 14 April, with new cases peaking on 26 
Fig. 1 The cumulative Covid-19 cases, active Covid-19 cases, and daily Covid-19 cases in Malaysia (Department of Statistics Malaysia 2020)

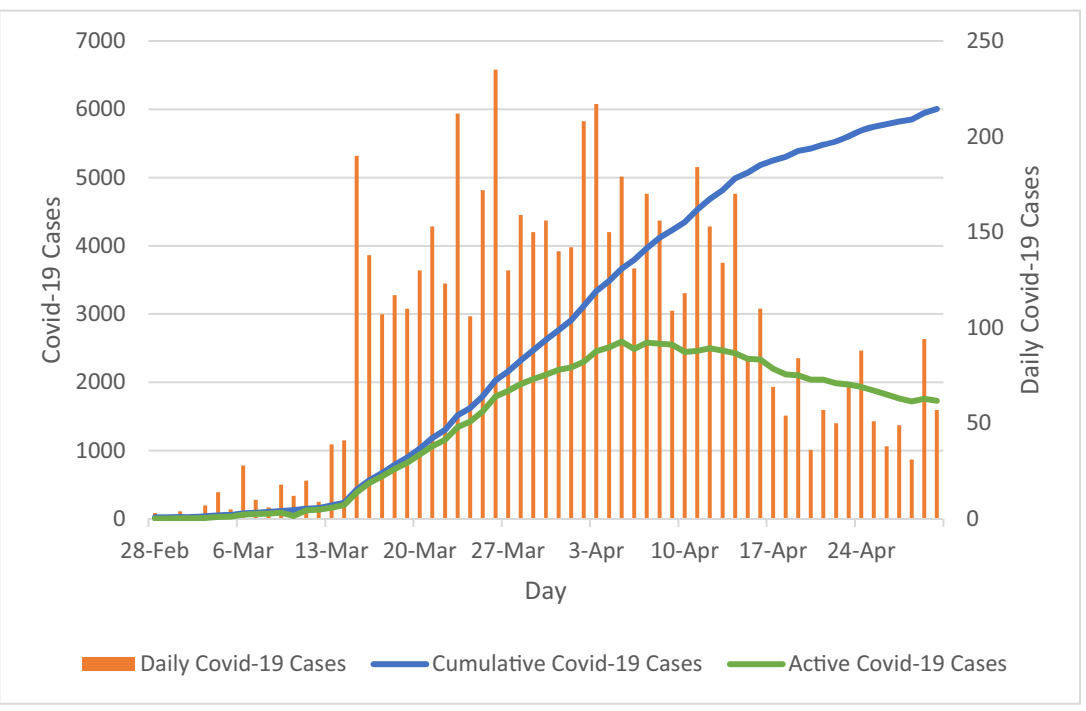

March at 235 (Fig. 1). Up to 30 April, the daily new cases crossed the 200 mark only four times (Fig. 1). Nonetheless, the active cases have been consistently lower than the total cases as infected individuals recovered from Covid-19 (Fig. 1).

\section{Measures taken by the Malaysian government to contain Covid-19}

The Malaysian government has been vigilant on Covid-19 since January 2020, starting with issuance of advice against travelling to China on 25 January after three Chinese citizens were tested positive for Covid-19 (Immigration Department of Malaysia 2020). After that, a series of measures has been rolled out as summarized in Table 1. The measures started with entry restriction of selective foreign nationals into Malaysia, as well as self-quarantine of Malaysian and nonMalaysian citizens returning from Covid-19 hotspots, and culminated with the passing and execution of the Movement
Control Order (MCO) (Immigration Department of Malaysia 2020; Ministry of Health 2020; Prime Minister's Office of Malaysia 2020a).

\section{Effectiveness of the movement control order}

The 2020 MCO, often referred to as partial lockdown, signifies a major step taken by the Malaysian Government to contain the Covid-19 pandemic. Akin to a cordon sanitaire, it prohibits mass movements and gatherings at all places nationwide including religious services, and demands closure of all business premises except manufacturers, suppliers, retailers, and food outlets (Kumar et al. 2020; Prime Minister's Office of Malaysia 2020b). The order escalates travel restrictions, with sanctions required for all Malaysians travelling overseas as well as continued medical screening and 14-day quarantine of returning Malaysians. In addition, all foreign visitors are prohibited from entering Malaysia (Prime
Fig. 2 Cumulative cases of death caused by Covid-19 in Malaysia (Department of Statistics Malaysia 2020)

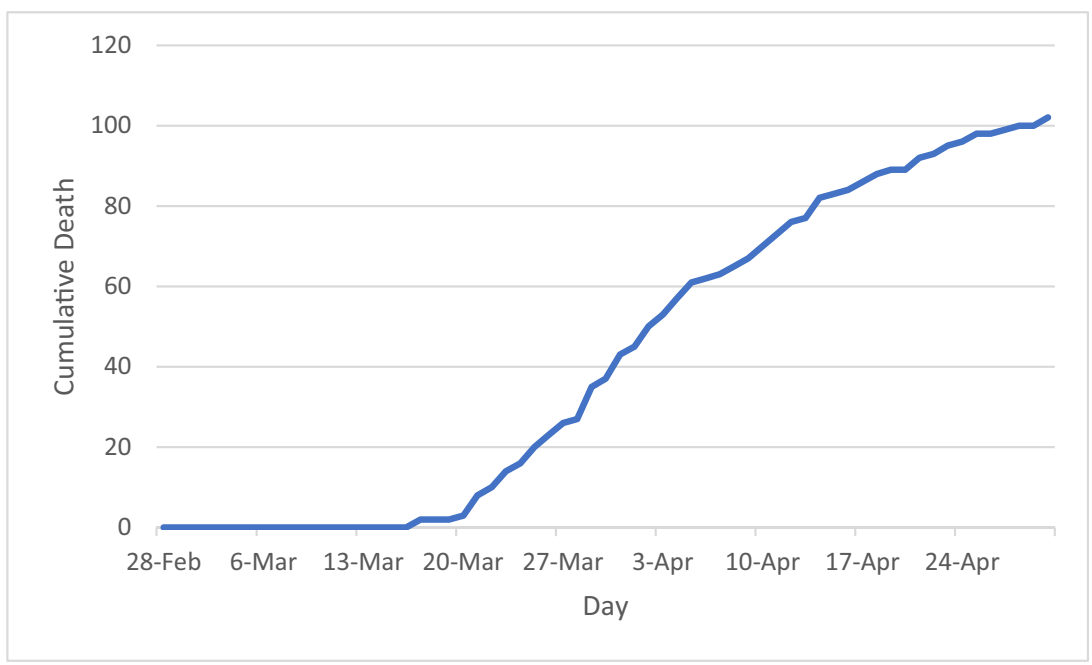


Table 1 Covid-19 containment measures in Malaysia (Bernama 2020a, 2020b; Ministry of Health Malaysia 2020; Prime Minister's Office of Malaysia 2020a, 2020b)

\begin{tabular}{|c|c|}
\hline Date & Measure \\
\hline 27 Jan 2020 & $\begin{array}{l}26 \text { hospitals were identified as centres for further examination and treatment of individuals with suspected Covid-19 infection. } \\
\text { The entry of Chinese nationals from Wuhan city and Hubei province was suspended. }\end{array}$ \\
\hline 28 Jan 2020 & $\begin{array}{l}\text { A committee comprising the National Disaster Management Agency, the Ministry of Foreign Affairs, the Ministry of Health, the } \\
\text { Malaysian Armed Forces, and the National Security Council was established to facilitate the return of Malaysians from the } \\
\text { Hubei province of China. } \\
\text { The Sabah Government suspended all flights to China. }\end{array}$ \\
\hline 1 February 2020 & $\begin{array}{l}\text { All Chinese citizens and non-Malaysian citizens who visited China in the last } 14 \text { days were prohibited from entering Sarawak. } \\
\text { Those with employment passes, student passes, or long-term social visit passes had a 14-day self-quarantine imposed }\end{array}$ \\
\hline 8 February 2020 & $\begin{array}{l}\text { Travel restriction was imposed in Sabah on non-Sabah citizens and 14-day self-quarantine mandated for Sabah citizens with } \\
\text { recent travel history to or returning from China. }\end{array}$ \\
\hline 11 February 2020 & $\begin{array}{l}\text { Agreement was attained between Malaysia and Singapore to form a Covid-19 containment joint committee headed by the } \\
\text { deputy health ministers of both nations. }\end{array}$ \\
\hline $\begin{array}{l}5 \text { March }-14 \\
\quad \text { March } 2020\end{array}$ & $\begin{array}{l}\text { The Malaysian Government expanded the travel restriction list, and began full restriction of foreign nationals coming from Italy, } \\
\text { Iran, and South Korea on } 13 \text { March. }\end{array}$ \\
\hline 16 March 2020 & The Prime Minister of Malaysia announced the implementation of the MCO commencing on 18 March. \\
\hline 18 March 2020 & The first phase of the MCO came into effect until 31 March. \\
\hline 25 March 2020 & Announcement was made on the extension of the MCO from 1 April to 14 April, namely the second phase of the MCO. \\
\hline 10 April 2020 & Announcement was made on the extension of the MCO from 15 April to 28 April, namely the third phase of the MCO. \\
\hline 21 April 2020 & Announcement was made on the extension of the MCO from 29 April to $12 \mathrm{May}$, and this is called the fourth phase of the MCO. \\
\hline 1 May 2020 & $\begin{array}{l}\text { Conditional MCO which allowed conditional resumption of certain businesses to ease economic losses was announced. The } \\
\text { businesses excluded those requiring close contacts and crowding such as cinemas, entertainment centers, exhibitions and } \\
\text { theme parks. States were given autonomy in their adoption of the conditional MCO. }\end{array}$ \\
\hline
\end{tabular}

Minister's Office of Malaysia 2020c). Learning institutions of all types at all levels were closed in addition to all government and private premises, except providers of essential services comprising energy and electricity, telecommunication, water, postal, oil and gas, fuel, finance and banking, health, firefighting, defence, transportation and logistics, defence, and food. Violators of the MCO are subject to a fine amounting to RM1000 and a maximum of 6 months imprisonment (Prime Minister's Office of Malaysia 2020c).

The MCO triggered considerable movements prior to its implementation, with Malaysian citizens travelling back home. Such movements, together with other movements at the commencement of the MCO prior to a stricter enforcement, characterized by localized gathering at markets and vacation spots, increased the risk of Covid-19 transmission, which was linked to the upsurge of daily Covid-19 cases over the following 14 days, peaking on 26 March (Salim et al. 2020). Subsequently, the MCO saw progressively more stringent enforcement, with road blocks established across the country and the military forces mobilized to enhance $\mathrm{MCO}$ enforcement (Bernama 2020c). From 1 April onwards, operating hours of all businesses were limited to 8 am to $8 \mathrm{pm}$, and all citizens were confined to a $10-\mathrm{km}$ travel radius while traveling for the purchase of essentials was limited to only one person at one time from each household (Bernama 2020c). Residents in locations identified as hotspots of Covid-19 underwent stricter MCO, with prohibition of permanent and temporary residents in those areas from leaving their homes and prohibition of non-residents from entering. Food was provided by the government to the affected individuals, and medical bases were set up in those areas (Prime Minister's Office of Malaysia 2020d).

The official media have been instrumental in providing updates of the MCO and urging all individuals nationwide to stay home, minimize unnecessary travel, practice personal hygiene, and keep social distances throughout the effective period of the MCO. Stringent enforcement has resulted in improved compliance to the $\mathrm{MCO}$ during its second and third phases (Zolkepli and Sivanandam, 2020). The notable decrease of daily new Covid-19 cases after 14 April (Fig. 1) can very likely be attributed to improved compliance to the MCO through more stringent enforcement, in addition to continuous medical screening and tracking of suspected contacts with the Covid-19 infected individuals. The decrease is also captured by an easing gradient of the cumulative Covid-19 cases in Malaysia (Fig. 1). Reduction in active Covid-19 cases is evident since 5 April, with more infected individuals recovering than new Covid-19 cases (Fig. 1). With daily Covid-19 diagnosis showing a downtrend, more businesses are allowed to resume operation, including manufacturers of packaging and printing materials, hardware stores, laundries, barbers, and optometrists, with conditions applied (Koya 2020). 


\section{Conclusion}

Malaysia has implemented multiple measures to contain the Covid-19 pandemic since January 2020, culminating in the execution of the MCO. Though doubts on effectiveness of the MCO were raised at the early stage of its implementation as mass movements persisted, strict enforcement and improved awareness of the impacts of Covid-19 have brought significant improvement in compliance, which has been deemed the main reason behind the decrease in new Covid19 cases since mid-April. Based on the downtrends of new and active Covid-19 cases, it can be concluded that the MCO has been effective, provided that compliance to the MCO is maintained. The Malaysian experience points to compliance and cooperation of the public as essential elements for the success of interventions by the government to contain Covid-19. Nonetheless, the socioeconomic implications of such interventions require attention and proper handling.

Authorship contribution statement Kuok Ho Daniel Tang is the sole author of this short communication.

Role of funding source This study is not funded by any grants, institutions, or individuals

\section{Compliance with ethical standards}

Conflict of interest No conflicts of interest have been identified for this study.

Ethical approval This study does not require ethical approval.

\section{References}

Bernama (2020a) Chronology of Covid-19 in Malaysia. Retrieved from: https:/www.newsarawaktribune.com.my/chronology-of-covid-19in-malaysia/ [Accessed 20/4/20]

Bernama (2020b) MCO extended until April 28 - PM Muhyiddin. Retrieved from https://www.bernama.com/en/general/news_covid19.php?id=1830577 [Accessed 20/4/20]

Bernama (2020c) MCO: Travel now restricted to 10-km radius. Retrieved from https://www.bernama.com/en/general/news.php?id=1827627 [Accessed 20/4/20]

Department of Statistics Malaysia (2020) Current statistics: Covid-19 by states in Malaysia. Retrieved from https://www.dosm.gov.my/v1/ i n d e x.ph p ? r = c o 1 u m n / con e \& m e n u i d = UjJoNk9OalhZWlVHdExiaGF1OW13UT09 [Accessed 20/4/20]

Immigration Department of Malaysia (2020) Covid-19 (latest announcement). Retrieved from https://esd.imi.gov.my/portal/latest-news/ announcement/announcement-convid19-latest/ [Accessed 21/4/20]

Koya Z (2020). Govt allows more businesses, like hair salon, optometry, to open during MCO. Retrieved from https://www.thestar.com.my/ news/nation/2020/04/10/govt-allows-more-businesses-like-hairsalon-optometry-to-open-during-mco [Accessed 22/4/20]

Kumar D, Malviya R, Sharma PK (2020) Corona virus: a review of COVID-19. Eurasian J Med Oncol 4:8-25

Ministry of Health Malaysia (2020). Covid-19 (latest updates). Retrieved from http://www.moh.gov.my/index.php/pages/view/2019-ncovwuhan [Accessed 20/4/20]

Prime Minister's Office of Malaysia (2020a). Coronavirus Disease 2019 (Covid-19). Retrieved from https://www.pmo.gov.my/specialcontents/2019-novel-coronavirus-2019-ncov/ [Accessed 20/4/20]

Prime Minister's Office of Malaysia (2020b). Movement Control Order: FAQ \& info. Retrieved from https://www.pmo.gov.my/2020/03/ movement-control-order-faq-info/ [Accessed 20/4/20]

Prime Minister's Office of Malaysia (2020c). Restriction of Movement Order. Retrieved from https://www.pmo.gov.my/2020/03/ movement-control-order/ [Accessed 21/4/20]

Prime Minister's Office of Malaysia (2020d). Enhanced Movement Control Order (EMCO) at Selangor Mansion and Malayan Mansion, KL. Retrieved from https://www.pmo.gov.my/2020/04/ enhanced-movement-control-order-emco-at-selangor-mansion-andmalayan-mansion-kuala-lumpur/ [Accessed 21/4/20]

Pung R, Chiew CJ, Young BE, Chin S, Chen MI, Clapham HE, Cook AR, Maurer-Stroh S, Toh MP, Poh C, Low M (2020) Investigation of three clusters of COVID-19 in Singapore: implications for surveillance and response measures. Lancet 395(10229):1039-1046

Salim N, Chan WH, Mansor S, Bazin NE, Amaran S, Faudzi AA, Zainal A, Huspi SH, Khoo EJ, Shithil SM (2020) COVID-19 epidemic in Malaysia. Impact of lock-down on infection dynamics. medRxiv. https://doi.org/10.1101/2020.04.08.20057463

See KC, Liew SM, Ng DC, Chew EL, Khoo EM, Sam CH, Sheena D, Filzah MZ, Chin SY, Lee PY, Tan LP (2020) COVID-19: four paediatric cases in Malaysia. Int J Infect Dis 94:125-127. https:// doi.org/10.1016/j.ijid.2020.03.049

World Health Organization (2020). Coronavirus disease (Covid-19) situation report - 101. WHO, Geneva. Retrieved from https://www. who.int/docs/default-source/coronaviruse/situation-reports/ 20200430-sitrep-101-covid-19.pdf?sfvrsn=2ba4e093_2 [Accessed $30 / 4 / 20]$

Zolkepli F, Sivanandam H (2020). MCO compliance at $97 \%$ but 482 arrests over March 26-27. Retrieved from https://www.thestar. com.my/news/nation/2020/03/28/mco-compliance-at-97-but-482arrests-over-march-26-27 [Accessed 22/4/20]

Publisher's note Springer Nature remains neutral with regard to jurisdictional claims in published maps and institutional affiliations. 